
ior Lecturer, S. O. Chernenko ${ }^{3}$, student

\title{
RAYLEIGH WAVES ARISING IN THE COLLISION OF ELASTIC BODIES AND HERTZ IMPACT THEORY GENERALIZATION
}

Метою цієї роботи є розвиток та деяке узагальнення локальної теорії деформування пружних тіл при їх прямому центральному співударі. Розглядається вплив поверхневих хвиль, що спричиняються ударом, на процес удару. Як відомо, ще Релей відзначав, що цей вплив може бути суттєвим. Е роботі розглядаються сили інерції, на разі використання інтегрального перетворення Лапласа-Карсона до рівнянь еластодинамики, у результаті чого динамічна задача теорії пружності перетворюється на квазистатичну задачу щодо зображень шуканих величин.

Дослідження мінімальних властивостей контактного тиску виявило, що під час удару виникає спектр частот поверхневих хвиль, та найбільший вплив на процес удару надають хвилі найнижчої частоти. Коефіцієнт відновлення у цьому випадку наближається до класичного.

Ru Целью этой работы является развитие и некоторое обобщение локальной теории деформирования упругих тел при их прямом центральном соударении. Рассматривается влияние поверхностных волн, вызванных ударом, на процесс удара. Как известно, еще Релей отмечал, что влияние это может быть существенным. В работе рассматриваются силы инерции, посредством при-

\footnotetext{
${ }^{1}$ National Technical University of Ukraine "Igor Sikorsky Kyiv Polytechnic Institute", Department of Aircraft Control Devices and Systems

${ }^{2}$ National Technical University of Ukraine "Igor Sikorsky Kyiv Polytechnic Institute", Department of Aircraft Control Devices and Systems

${ }^{\mathbf{3}}$ National Technical University of Ukraine "Igor Sikorsky Kyiv Polytechnic Institute", Faculty of Aircraft and Space Systems
} 
менения к уравнениям эластодинамики интегрального преобразования Лапласа-Карсона, в результате которого динамическая задача теории упругости сводится к квазистатической задаче относительно изображений искомых величин.

Исследование минимальных свойств контактного давления показало, что при ударе возникает спектр частот поверхностных волн, и наибольшее влияние на процесс удара оказывают волны самой низкой частоты. Коэффициент восстановления в этом случае близок к классическому.

\section{Introduction}

The purpose of this work is the development and generalization of the local theory of elastic bodies deformation during their direct central collision. An issue of the surface waves influence caused by the impact on the impact process is considered. As it is known, Rayleigh noted that this influence could be significant.

\section{Problem statement and method solutions}

Let us turn to the collisions theory of solids and consider the H. Hertz theory of bodies local deformation under the impact (1). Only local deformations are taken into account in Hertz theory, the rest deformations are ignored. Meanwhile, it is not obvious that the transverse and longitudinal oscillations, occurring during the bodies collision, do not significantly affect the propagation of local stresses and deformations. Hertz proceeded from a simplified mechanical model of a system consisting of undeformed solids separated by a deformable "gasket." "Gasket" compression $\alpha$ determines the convergence of the centers of inertia of colliding bodies. The function $\alpha$ satisfies the equation

$$
m \ddot{\alpha}=-P ; \quad m=\frac{m_{1} m_{2}}{m_{1}+m_{2}},
$$

where $P$ - contact force, $m_{i}$ - solids' masses.

The dependence between $\alpha$ and $P$ is established from the solution of the static contact problem, i.e. with the use of the Lame equations with excluded inertia forces. We have:

$$
\alpha=k \mathrm{P}^{\frac{2}{3}} \text {. }
$$

Hertz did not take into account the inertia forces of the deformed bodies elements. However, there are sufficiently convincing proofs of the need to consider the local forces of inertia arising during elastic bodies collision (2). We consider the inertia forces by applying the Laplace-Carson integral transformation to the equations of elastodynamics, as a result of which the dynamic problem of the elasticity theory reduces to a quasistatic problem with respect to the images of the unknown quantities.

According to Hertz hypothesis in the Lame equation 


$$
\mu \nabla^{2} \vec{U}+(\lambda+\mu) \operatorname{graddiv} \vec{U}+\rho \vec{F}=\rho \frac{\partial^{2} \vec{U}}{\partial t^{2}} .
$$

the forces of inertia $\rho \frac{\partial^{2} \vec{U}}{\partial t^{2}}$ and mass forces $\rho \vec{F}$ are not taken into account. In the image space, this equation corresponds to

$$
\mu \nabla^{2} \vec{U}^{*}+(\lambda+\mu) \text { graddiv } \vec{U}^{*}=0 .
$$

The mechanism of integral transformation makes it possible to find a different meaning in this transition. The equation (3) is transform into the image space

$$
\mu \nabla^{2} \vec{U}^{*}+(\lambda+\mu) \operatorname{graddiv} \vec{U}^{*}+\rho\left(\vec{F}^{*}+p \overrightarrow{\dot{U}}_{0}+p^{2} \vec{U}_{0}-p^{2} \vec{U}^{*}\right)=0 .
$$

From the equation (5), the equation (4) can be obtained by setting

$$
\vec{F}^{*}+p \overrightarrow{\dot{U}}_{0}+p^{2} \vec{U}_{0}-p^{2} \vec{U}^{*}=0
$$

In the space of originals, this corresponds to the introduction of fictitious forces $\vec{F}=\rho \frac{\partial^{2} \vec{U}}{\partial t^{2}}$. These forces are an additional "source of energy". This becomes clear when determining the recovery factor: in this case it exceeds unity (3), which is obviously impossible.

Equation (4) is identical to the Lamé elastostatic equation. Applying the integral transformation to the kinematic contact condition and solving the equations of the quasi-static contact problem in the image space, we get the correlation

$$
\alpha^{*}=k \mathrm{P}^{* \frac{2}{3}} \text {. }
$$

It should be emphasized that the equation (7) is not the result of the Laplace-Carson transformation of the nonlinear correlation (2), but it is a nonlinear consequence of the linear equations of the elasticity theory in the image space.

It is necessary to clarify the analytical formulation of the problem. For this, a well-known method of integrating the elasticity theory equations indicated by Somilyan (the theorem on the reciprocity of work) can be applied.

The first or real state of the body is defined by the equation

$$
\mu \nabla^{2} \vec{V}^{*}+(\lambda+\mu) \text { graddiv } \vec{V}^{*}-\rho p^{2} \vec{V}^{*}=0,
$$

obtained on the basis of (4) under the assumption

$$
\vec{F}^{*}=0, \quad U_{0}=0, \quad \vec{U}^{*}=\frac{1}{p} \vec{U}_{0}-\vec{V}^{*} .
$$

The second or auxiliary state is determined by the equation

$$
\mu \nabla^{2} \vec{W}^{*}+(\lambda+\mu) \text { graddiv } \vec{W}^{*}=0
$$

with excluded forces of inertia, as well as boundary and initial conditions.

The integral equations obtained on the basis of the reciprocity theorem are as follows 


$$
V_{k}^{*}(\mathrm{M}, p)=W_{k}(\mathrm{M}, \mathrm{p})-\rho \mathrm{p}^{2} \iiint_{(v)} \sum_{j} G_{(k) j}(Q, \mathrm{M}) V_{j}^{*}(\mathrm{Q}, \mathrm{p}) \mathrm{dV}_{Q}, k=1,2,3 .
$$

An approximate solution of this system allows us to find the local compression image $\alpha^{*}{ }_{(p)}$ in the form.

$$
\begin{aligned}
\alpha^{*}(p) & =\left[\frac{\vartheta_{1}}{\vartheta_{1}+\vartheta_{2}}\left(1-\frac{\chi_{1}^{*} p^{2}}{(1)}\right)+\frac{\vartheta_{2}}{n^{2}+p^{2}}\left(1-\frac{\chi_{2}^{*} p^{2}}{(2)}\right)\right] \alpha_{1}^{*}(p)+ \\
& +\frac{1}{p}\left(\dot{U}_{30}^{(1)}+\dot{U}_{30}^{(2)}\right),
\end{aligned}
$$

Let us put the dimensionless parameters

$$
p=q \frac{V_{0}^{\frac{1}{5}}}{m^{\frac{2}{5}} k^{\frac{3}{5}}} ; \quad \stackrel{(i)}{n}=\stackrel{(i)}{m^{\frac{2}{5}} k^{\frac{3}{5}}} .
$$

In the space of originals, this corresponds to the introduction of dimensionless time

$$
\tau=t \frac{V_{0}^{\frac{1}{5}}}{m^{\frac{2}{5}} k^{\frac{3}{5}}} .
$$

Then

$$
\alpha^{*}(q)=k^{*}(q) \mathrm{P}^{* \frac{2}{3}}+k\left(\frac{m V_{0}^{2}}{k}\right)^{\frac{2}{5}} \frac{1}{q},
$$

where

$$
k^{*}(q)=k\left[1-\frac{\vartheta_{1}}{\vartheta_{1}+\vartheta_{2}} \frac{\chi_{1}^{*} q^{2}}{v^{2}+q^{2}}-\frac{\vartheta_{2}}{\vartheta_{1}+\vartheta_{2}} \frac{\chi_{2}^{*} q^{2}}{v^{2}+q^{2}}\right] .
$$

The function $k^{*}(q)$ contains two undefined functions $\chi_{i}^{*}$ and the oscillation frequencies that occur upon impact. These indefinite elements show that formula (15) covers a significant part of the consequences of the Lame equations. To find one of the possible choices of the function $k^{*}(q)$, let us turn to the surface waves theory caused by the collision of elastic bodies (4).

For bodies bounded by surfaces of revolution, the kinematic condition for bodies contact has the form

$$
\stackrel{(1)}{W}(\mathrm{M}, t)+\stackrel{(2)}{W}(\mathrm{M}, t)=\alpha(t)-\left[A+\frac{1}{2}\left(\frac{\partial^{2} V}{\partial r^{2}}\right)_{r=0}\right] r^{2} .
$$

$V$ - the vertical component of the displacement vector is determined by the equation 


$$
V=\left(\mathrm{M} \xi e^{-\xi z}+\mathrm{N} \kappa e^{-\eta z}\right) I_{0(\kappa r)}\left\{\begin{array}{l}
\cos \omega \mathrm{t} \\
\sin \omega \mathrm{t}
\end{array},\right.
$$

containing unknown parameters $\mathrm{M}, \mathrm{N}, \xi, \eta, \kappa, \omega$ (amplitude and frequency characteristics arising from the impact of Rayleigh waves). From the conditions of the absence of additional stresses on the surfaces of bodies, the correlations between these parameters follow (4). Solving the equation (16) in the space of images, we find

$$
\alpha_{s}^{*}(q)=k\left[1-\frac{\mathrm{B}}{\mathrm{A}} \frac{q^{2}}{\Omega^{2}+q^{2}}-\frac{\mathrm{B}}{\mathrm{A}} \frac{q^{2}}{\Omega^{2}+q^{2}}\right]^{\frac{(1)}{3}} \mathrm{P}^{* \frac{2}{3}}
$$

Here

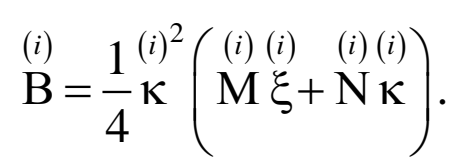

Thus, from the surface waves theory we have

$$
k_{s}^{*}(q)=k\left[1-\frac{\mathrm{B}}{\mathrm{A}} \frac{q^{2}}{\stackrel{(1)}{2}^{2}+q^{2}}-\frac{\stackrel{(2)}{\mathrm{B}} \frac{q^{2}}{(2)^{2}}}{\Omega+q^{2}}\right]^{\frac{1}{3}} .
$$

Identifying the indefinite elements in the equations (15) and (19)

$$
\begin{gathered}
\frac{\vartheta_{i}}{\vartheta_{1}+\vartheta_{2}} \chi_{i}^{*} \text { with } \frac{\mathrm{B}}{\mathrm{A}} \text { and } \stackrel{(i)^{2}}{\vee} \text { with } \stackrel{(i)^{2}}{\Omega}, \text { we find } \\
\alpha_{R}^{*}(q)=k_{R}^{*} \mathrm{P}^{* \frac{2}{3}},
\end{gathered}
$$

where

$$
k_{R}^{*}(q)=k\left[1-\frac{\mathrm{B}}{\mathrm{A}} \frac{q^{2}}{\stackrel{(1)}{\Omega}+q^{2}}-\frac{\stackrel{(2)}{\mathrm{B}} \frac{q^{2}}{(2)^{2}}}{\Omega+q^{2}}\right]^{\frac{4}{3}} .
$$

Here the index $R$ shows the presence of Rayleigh waves caused by impact. If this identification is not made, then we get

$$
\alpha^{*}(q)=k^{*}(q) \mathrm{P}^{* \frac{2}{3}} \text {, }
$$

where 


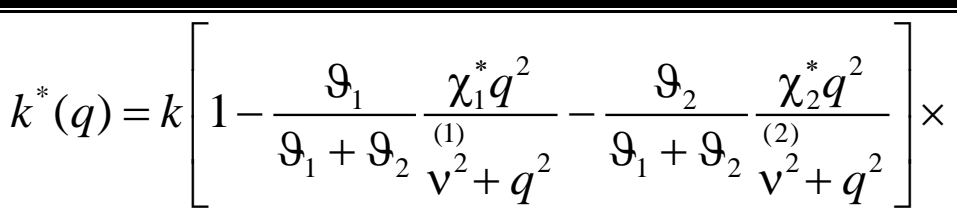

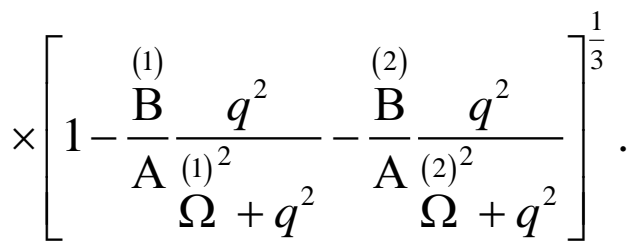

\section{Conclusions}

The research of the minimum properties of the contact pressure showed (4) that upon impact a spectrum of surface wave frequencies arises, and waves of the lowest frequency have the greatest impact on the impact process. The recovery coefficient in this case is close to the classical one, $\varepsilon \cong 0,68$ (5).

\section{References}

1. Kilchevsky N. A. Dynamic contact compression of solids. Hit., "Naukova dumka", Kiev, 1976.

2. Lavrentyev M. A., Shabat B. V. Methods of the theory of functions of a complex variable, Gostekhizdat, Moscow, 1958.

3. Kilchevsky N. A., Shalda L. M. Izvestiya of the USSR Academy of Sciences, MGT, No. 6, 1973.

4. Kilchevsky N. A., Ilchishina D. I. Applied Mechanics, V. 5, No. 7, 1968

5. Ilchishina D. I. Report of AS USSR, No. 4, 1975. 